УДК 616.24 - 002:616.12-005.4

DOI

\title{
ВПЛИВ ІШЕМІЧНОЇ ХВОРОБИ СЕРЦЯ ТА МЕТАБОЛІЧНОГО СИНДРОМУ НА ПОКАЗНИКИ ФУНКЦІї ЗОВНІШНЬОГО ДИХАННЯ У ХВОРИХ НА ХРОНІЧНЕ ОБСТРУКТИВНЕ ЗАХВОРЮВАННЯ ЛЕГЕНЬ
}

\author{
○С. І. Треумова, $€$. Є. Петров, Ю. Г. Бурмак, Т. А. Іваницька \\ Вищий державний навчальний заклад України "Українська медична стоматологічна академія», \\ м. Полтава
}

Хронічне обструктивне захворювання легень (ХОЗЛ)-одна з найважливіших медико-соціальних проблем як в Україні, так і у світі. Коморбідним фоном, на якому маніфестує ХОЗЛ, часто $є$ метаболічні порушення, ішемічна хвороба серця (IXC), артеріальна гіпертензія. Поширеність метаболічного синдрому (МС) серед хворих на ХОЗЛ складає від 21 до 53 \%, особливо на ранніх стадіях його розвитку. Тому детальне вивчення взаємного впливу вищезгаданої патології набуває актуальності.

Мета дослідження - оцінка показників функції зовнішнього дихання у хворих на ізольоване ХОЗЛ у поєднанні з IXC та на тлі метаболічного синдрому.

Матеріал і методи дослідження. Обстежено 50 осіб, у тому числі 40 хворих на ХОЗЛ ІІ ст. Із них - 15 хворих на ХОЗЛ ІІ ст. в поєднанні з ІХC без MC (1 група); 15 хворих з діагностованим МС (2 група). Порівняльну групу склали 10 хворих на ізольоване ХОЗЛ II ст. Серед обстежених чоловіків було 22 (55,0 \%), жінок - 18 (45,0 \%) у середньому віці $(58,9 \pm 1,2)$ роки. Усі групи були ідентичні за віком, статтю та тяжкістю перебігу захворювання. Контрольну групу склали 10 здорових осіб. Діагноз, ступінь тяжкості ХОЗЛ встановлювали згідно з наказом МОЗ України № 128 від 12.03.07 та з положеннями, сформульованими в документі GOLD (Global Initiative for Chronic Obstructive Lung Disease) на основі даних анамнезу, загальноклінічного обстеження, електрокардіографії (ЕКГ), рентгенографії органів грудної клітки, показників функції зовнішнього дихання (ФЗД). Обстежені хворі на ХОЗЛ мали II стадію, помірний ступінь. Діагноз
IXC ґрунтувався на даних анамнезу, ЕКГ, показниках ехокардіографії. Вивчення ФЗД проводили на спірометрі Спіросіфт-3000 (Японія) із аналізом наступних показників: число дихань, хвилинний об'єм дихання, життєва ємність легень, форсована життєва ємність легень, індекс Тіффно, максимальна вентиляція легень, максимальна об'ємна швидкість $(25,50,75$ \%), пікова швидкість видиху; проводили пневмотахометрію вдиху, видиху. Вираховували зворотність бронхіальної обструкції.

Результати дослідження показали, що у хворих з ізольованим ХОЗЛ вже наявні порушення показників ФЗД: життєвої ємності легень, максимальної вентиляції легень, об'єму форсованого видиху за 1 секунду, форсованої життєвої

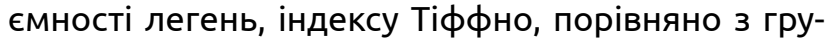
пою здорових осіб. Ці порушення зростають при поєднанні ХОЗЛ з ІХC внаслідок не тільки розвитку легеневої недостатності, а й дисфункції лівого шлуночка та лівошлуночкової недостатності. При приєднанні МС ці показники ще більше погіршуються, дихальні порушення набувають переважно змішаного типу, на відміну від ізольованої ХОЗЛ (переважно обструктивний тип).

Висновки. Отримані результати є свідченням виникнення синдрому взаємного обтяження у хворих на ХОЗЛ в поєднанні з IXC (особливо при наявності MC).

Перспективи подальших досліджень. В подальшому плануємо вивчення показників функціонального стану шлуночків серця у хворих на хронічне легеневе серце бронхолегеневого ґенезу в поєднанні з IXC на тлі MC. 